\title{
Benign Basal Cell Neoplasm
}

National Cancer Institute

\section{Source}

National Cancer Institute. Benign Basal Cell Neoplasm. NCI Thesaurus. Code C4743.

A neoplasm composed of basal cells that remains localized and does not metastasize to other anatomic sites. 